\title{
Sustaining angiosperms' diversity of Bood Promontory and Eco-Park, Butuan City, Philippines: Step towards a community based-protection management program
}

\author{
JULIE S. BERAME ${ }^{1, \boldsymbol{\varphi}}$, MINIE L. BULAY ${ }^{1,2}$, RISSA M. MERCADO ${ }^{1,3}$ \\ ${ }^{1}$ College of Education, Caraga State University. Ampayon, Butuan City 8600, Philippines. Tel. +63-9199222449, "email: janveel@ yahoo.com \\ ${ }^{2}$ Department of Science Education, University of San Carlos. P. del Rosario Street, Cebu City 6000, Philippines \\ ${ }^{3}$ Department of Education, University of San Carlos. P. del Rosario Street, Cebu City 6000, Philippines
}

Manuscript received: 12 April 2021. Revision accepted: 31 May 2021.

\begin{abstract}
Berame JS, Bulay ML, Mercado RM. 2021. Sustaining angiosperms' diversity of Bood Promontory and Eco-Park, Butuan City, Philippines: Step towards a community based-protection management program. Biodiversitas 22: 2519-2527. Bood Promontory and Eco-Park (Butuan City, Philippines) is a non-protected 72-hectare agroforestry land, disputed by two barangays. Its existence is rich historically, but the presence of important plant species, the angiosperms, attracted people which caused their number declining recently. Therefore, this study explored the flora using a line transect method through random sampling to provide valuable inputs necessary to back up the promulgation for a community based-protection management program in the area. Results found that 291 angiosperms accounted for 11 tree species, 4 herbs, 1 shrub, and 5 unnamed species. Trees made up 75\% of the area, dominated by Mahogany (Swietenia macrophylla, King), and 50\% of plant species are unassessed. Yakal, Philippine Teak, Antipolo, Narra, Mahogany, and Molave are in the IUCN Redlist for critically endangered and vulnerable statuses commonly used for construction materials, boat making, furniture, carvings, plywood, and firewood, putting them into peril and destruction if left unprotected. There were no recognized organizations, yet partial participation of the barangay council in forest protection and monitoring management can help angiosperms sustaining their existence. The City Tourism and DENR have to accelerate the claim for protecting the area and implement fully functional participation of locals to sustain and protect the vulnerability of angiosperm species.
\end{abstract}

Keywords: Angiosperms, community based-protection management program, diversity, eco-park, IUNC Redlist

\section{INTRODUCTION}

Angiosperms represent the largest class of plant life on Earth (Christenhusz and Byng 2016). They are the most diverse clade or group of plants in the Kingdom Plantae that has an estimated 295,383 flowering plant species and represent more than 80 percent of the current living green plants in the world (Hawkins et al. 2011). They are found in almost any environment, so long as there is sunlight, a form of water, and a way to spread their offspring (DENRAPWB 2019). In the Philippines, there are more than 8,000 species of the angiosperm present, 480 species of which are threatened according to the 2002 IUCN red list, and there are only 33 gymnosperm which has 11 threatened plant species. The rest are embodied by the vascular plant, such as the ferns and other non-vascular plants. The Philippine flora represents $5 \%$ of the world's flora, according to the Department of Environment and Natural Resources (DENR) and is still increasing due to its continuous evolution (Maiti et al. 2016).

Essentially, the diversity of species is a keyword that best describes an evergreen place (García-Quintana et al 2020). Two of these are the Bood Promontory and EcoPark, located in two conflict barangays of Pinamanculan and Libertad in Butuan City, Philippines. It is abundant in many aspects of its existence as an ecological ( $\mathrm{Wu}$ and $\mathrm{Li}$ 2018) park and historical locus. This disputed land, covering 72 hectares, has been occupied by 5832 residents of two barangays in Butuan City, Agusan del Norte. The majority livelihood of local communities near the eco-park is farming and fishing, utilizing the vast area of the place. It is grown with various plant species, particularly the angiosperms that play a very significant role in the lives of the farmers as their major sources of food and livelihood (Volis 2016) making their presence attractive and susceptible to overconsumption of lumber (Yu 2020), including the construction of posts, beams, decking, furniture, trim, and some other construction and structural purposes (PFS-DENR 2019). These angiosperms (flowering plants) are trees, shrubs, various flowers, and grasses common in the area to make the ambiance refreshing as it is also near Masao River. This historic river is connected to Butuan Bay (Estrella 2016).

The park is currently dominated by critically endangered trees such as Philippine Teak Tree (Tectona philippinensis Benth. \& Hook, f.) with a local name "Hadlayati," reddish hue which attracts the fireflies. This tree will glow during the night and was said to play an important role in the findings of place by Ferdinand Magellan, as claimed by the local historians (Amano et al. 2020). The term "bood" means "hill" in the Butuanon dialect. It holds a historical significance for it is the location of the gold industry and trading port of the province in the early 10th to 13 th Centuries of the Ancient 
Butuan (Capistrano-Baker 2016). The disputed area is a commemoration site of the cross planting after the First Easter Mass in the Philippines by the great navigator Ferdinand Magellan in the late 15th Century (D'Arcy 2018). The famous saying of the local historians was, "there was still no Philippines, but there was already Butuan," as the early civilization and commerce in 10th century has started long before in the place (Yu 2020). During that time, barter trading of the local folks was practiced the same as other neighboring countries like China, Malaysia, India, and other Asian Kingdoms had existed before the coming of the Spaniards. The long stretch of Masao River close to the eco-park is said to be the trading zone as it connects to Butuan Bay where Magellan's boat group anchored (Araneta 2021). The richness of the scenery as enveloped by various species of angiosperms make it a haven for local folks and tourists, both local and foreign, to visit and appreciate its green environment.

Presently, the City Tourism of Butuan City manages eco-park along with the Local Government and Barangay Units (LGUs) in cooperation with the local folks of the two disputed barangays covered by Bood Promontory and EcoPark. Thus, in this paper, the researchers would like to determine the diverse angiosperms species of the place as important resources utilized by the locals in various ways and provide relevant inputs necessary in resolving the conflicts between the two barangays and back up the claim for a community based-protection management in the area.

\section{MATERIALS AND METHODS}

\section{Study site}

The eco-park is situated at a bend in the Masao. The river is known as El Rio de Butuan. A huge cross will welcome people to Bood Promontory and Eco-Park. The cross replaces the original one that was used during the First Christian Mass in the country which took place last March 31, 1521 (Jackson 2020). There are statues of Ferdinand Magellan, Kalambu (King of Butuan), and Siaui (King of Mazaua) commemorating the mass in the ecopark. Tables and shed pavilions are available in the area for those who love to have a picnic in the place since the area is distributed with trees.

The hill site witnessed the significant events that happened centuries ago where the eco-park shadowed the ancient Butuan Bay and Masao River. The local tourists visit the elevated park adjacent to the coastline settlement of the present known Masao is presumed to be the tradeoff center of the ancient Butuan with far-reaching acquaintances to numerous Asian Kingdoms as a gold center industry in $10^{\text {th }}$ to $13^{\text {th }}$ century (Gamas 2020). After the $13^{\text {th }}$ Century, the ancient Butuan began succession from its height as an important trading port in Mindanao Island and extent it is trading to Sulu where ancient Tausugs (local Muslim Tausugs) traced their ethnic kinships to Butuan pay a visit to their homeland and plant the Hadlayati tree on this very site in Masao. Figure 1 shows the location of Butuan City, particularly in Bood Promontory and Eco-Park in Barangays Pinamanculan and Libertad, Butuan City, Philippines.
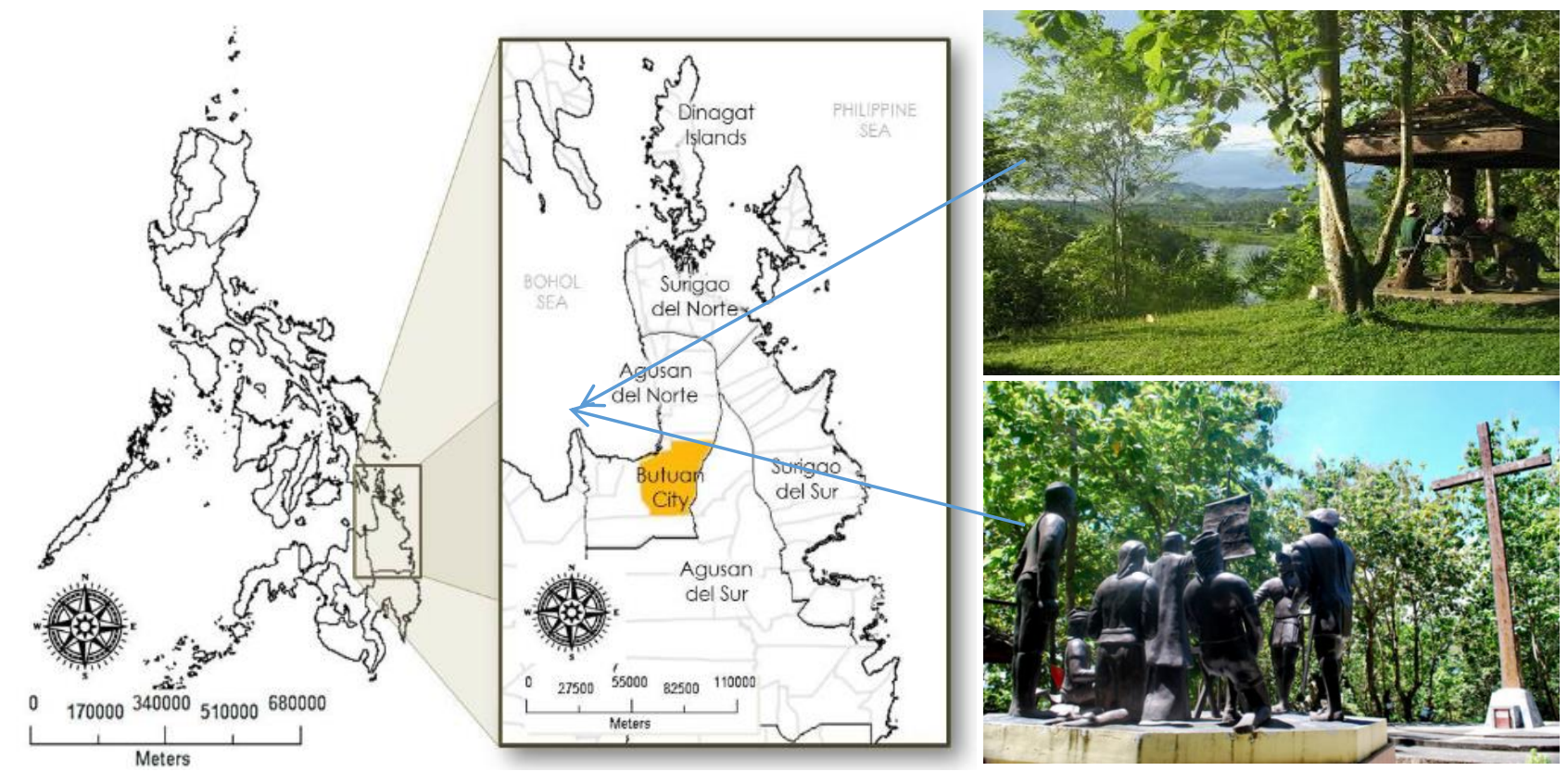

Figure 1. Bood promontory and eco-park in Pinamanculan, Butuan City, Philippines. (Source: Butuan City Tourism Council 2021) 


\section{Data management collections}

The ecological management protocol adopted in 2013 guided the study, which hierarchically structured into principles from environmental certification protocols (http://www.pactomataatlantica.org.br/pub-licacoes). The researchers considered touching the socio-environmental diagnosis and management protocols as well as lists of regional and planted species, data and photographic records, mapping, and other information to assist in understanding possible causes of protection success. The application of the Management The principle can identify gaps in the various protection implementation activities that are likely to lead to an unsuccessful protection program and enable stakeholders to communicate their successful experiences previously in the area.

Socio-economic principle indicates that the relationship between the concerned agencies and the surrounding communities is central to assess whether a participatory approach is being followed, which is ethically appropriate and essential to long-term initiative viability. Data for this principle were collected using semi-structured interviews of stakeholders, farmers' observations, and document analysis. The general recommendation is to evaluate forest restoration programs every 3 years. On the other hand, the researchers collected the management principal data the same way described in the socio-economic principle. The protocol suggests writing a brief initiative report summarizing the monitoring data and highlighting the most relevant positive and negative points related to management and socio-economic impacts.

In general, the study has observed these ecological protocols before the conduct of the study. Thereafter, the researchers sent a request letter to the barangay officials. After they secured the permit, an inventory of the angiosperm species had started using the line transect method through continuous sampling in the study area. Ten stations were chosen, with a width of 10 meters on both sides of the trail and an interval of 50 meters between stations. The angiosperm species were manually identified and listed, guided by their resident forest technicians to ensure and correct plants' identity. Then, identification of the plants was conducted in the Department and Natural Resources (DENR) to determine the validity and reliability inventory of the plants' scientific names and IUCN status. The field inventory of all identified species lasted for one week in June 2019. Then, they interviewed respondents to gather various relevant information on eco-park management, protection, and historical cornerstone. The research team was composed of personnel guides and forest technicians.

\section{RESULTS AND DISCUSSION}

At the study site, the team found 291 samples of angiosperms from 20 species, 11 trees from 8 families, namely, Arecaceae, Dipterocarpaceae, Elaeocarpaceae, Fabaceae, Meliaceae, Moraceae, Myrtaceae, and Verbenaceae; 4 herbs from 2 families, the Musaceae and Poaceae; 1 shrub species, Fabaceae, and 5 unidentified angiosperm plants.

As presented in Table 1, the Large-leaf Mahogany ( $S$. macrophylla, King) has the highest counts, and only 1 shrub species is present, the Makahiya (Mimosa pudica, L.) that grows abundantly in tropical places (Ahmad et al. 2012; Larekeng 2019). There were 4 tree species, and 1 herb species which are still unnamed.

Figure 2 shows the percentage composition of the angiosperm species with Large-leaf Mahogany containing the highest species composition of $12 \%$ among other angiosperm species in the site as a common reforestation tree used because of readily available seed from international seed banks and well-established nursery protocols and silvicultural treatments for this species (Chechina and Hamann 2016) and followed by Molave ( $V$. parviflora, Juss.) which made up only of $9 \%$. This is a slow-growing tree and requires $2 \mathrm{~m} \times 6 \mathrm{~m}$ space for plantations (CIFOR 2019).

There are other plant species in the area that are not covered in the quadrat sampling due to their remote location which might also require assessment for sustainability. The presence of many coconut trees (Cocos nucifera L.), bananas (Musa acuminata Colla), bamboo grasses (Bambuseae), and nips (Nypa fruticans Wurmb.) along Masao Riverbanks is an indication that food and income sources are highly abundant in the area.

Table 1. Counts of angiosperm species in the sampling site

\begin{tabular}{lc}
\hline Plant names & Quantity \\
\hline & \\
Yakal (Shorea astylosa, Foxw.) & 23 \\
Philippine Teak (T. philippinensis Benth. \& Hook.f.) & 19 \\
Antipolo (Artocarpus blancoi, (Elmer) Merr.) & 14 \\
Ipil-ipil (Leucaena leucocephala, (Lam.) de Wit) & 13 \\
Coconut (Cocos nucifera, L.) & 12 \\
Bagras (Eucalyptus deglupta, Blume & 7 \\
Large-leaf Mahogany (S. macrophylla, King) & 35 \\
Molave (Vitex parviflora, Juss.) & 27 \\
Guava (Psidium guajava, L.) & 16 \\
Narra (Pterocarpus indicus, Willd.) & 10 \\
Datiles (Muntingia calabura, L.) & 7 \\
Banana (Musa acuminata, Colla) & 14 \\
Makahiya (M. pudica, L.) & 19 \\
Rosaria grass & 25 \\
Cogon (Imperata cylindrica, (L.) Raeusch.) & 13 \\
Unnamed Tree 1 & 13 \\
Unnamed Tree 2 & 10 \\
Unknown Tree 3 & 5 \\
Unknown Tree 4 & 14 \\
Unnamed Herbs & 7 \\
Total & $\mathbf{2 9 1}$
\end{tabular}




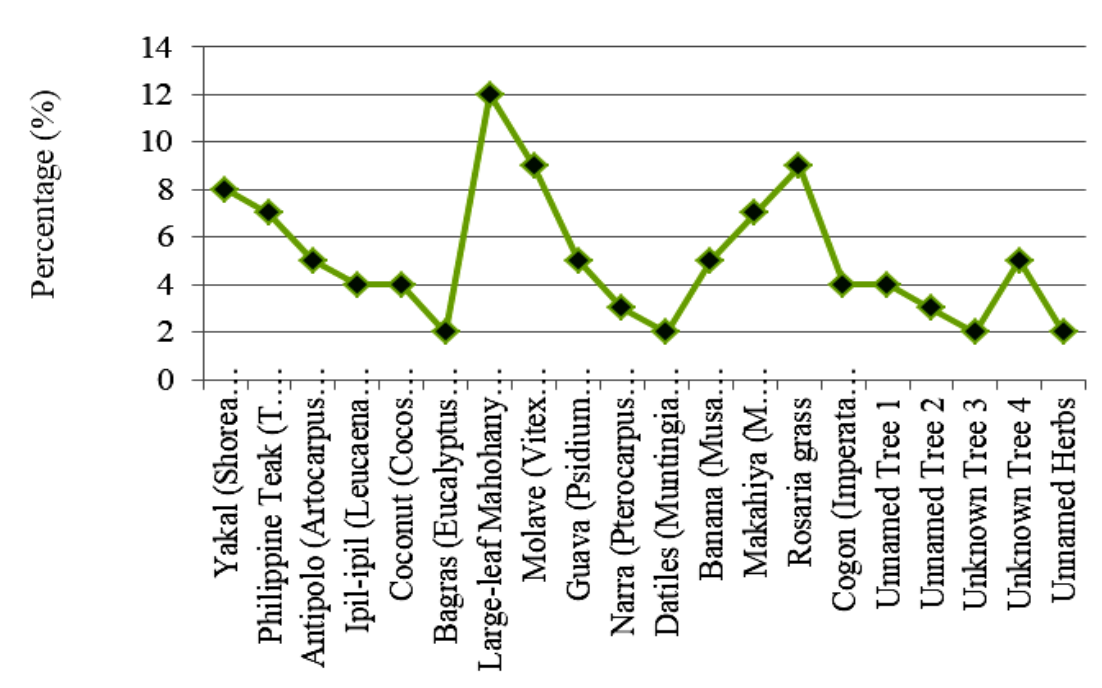

Figure 2. Percentage composition of species in bood promontory and eco-park

Table 2. The conservation status (IUCN) and uses of various angiosperm species in the study site

\begin{tabular}{|c|c|c|c|c|c|}
\hline Plant name & Family & Scientific name & $\begin{array}{c}\text { English/ local } \\
\text { name }\end{array}$ & IUCN status & Uses \\
\hline Yakal & Dipterocarpacea & S. astylosa, Foxw. & Yakal & $\begin{array}{l}\text { Critically } \\
\text { endangered }\end{array}$ & $\begin{array}{l}\text { Heavy construction, boat building, vats, } \\
\text { casks, decking, linings, joinery, fencing, } \\
\text { flooring and framing. }\end{array}$ \\
\hline $\begin{array}{l}\text { Philippine } \\
\text { Teak }\end{array}$ & Lamiaceae & $\begin{array}{l}\text { T. philippinensis, } \\
\text { Benth. \& Hook.f. }\end{array}$ & Hadlayati & $\begin{array}{l}\text { Critically } \\
\text { endangered }\end{array}$ & Construction, building materials, firewood \\
\hline Antipolo & Moraceae & $\begin{array}{l}\text { A. blancoi, (Elmer) } \\
\text { Merr. }\end{array}$ & Tipolo & Vulnerable & $\begin{array}{l}\text { Carvings, light construction, leaves, fruits } \\
\text { and seeds for food, leaves as mosquitoes } \\
\text { repellent, suspending agent and antimicrobial } \\
\text { agent }\end{array}$ \\
\hline Narra & Fabaceae & P. indicus, Wild. & Amboyna/Narra & Vulnerable & $\begin{array}{l}\text { Floorings, cabinetry, construction, furniture } \\
\text { making, decorative carvings, and musical } \\
\text { instruments, boat-making, source of red dye, } \\
\text { flower as source of honey, medicinal }\end{array}$ \\
\hline $\begin{array}{l}\text { Large-leaf } \\
\text { Mahogany }\end{array}$ & Meliaceae & $\begin{array}{l}\text { S. macrophylla, } \\
\text { King }\end{array}$ & Mahogany & Vulnerable & $\begin{array}{l}\text { Shade tree, bark for dyeing and tanning } \\
\text { leather, high-class furniture and cabinetwork, } \\
\text { plywood and heavy construction work }\end{array}$ \\
\hline Molave & Lamiaceae & $\begin{array}{l}\text { Vitex parviflora, } \\
\text { Juss. }\end{array}$ & Tugas & Vulnerable & $\begin{array}{l}\text { Durable furniture, boats, utensils, and as } \\
\text { construction materials }\end{array}$ \\
\hline Ipil-ipil & Fabaceae & $\begin{array}{l}\text { L. leucocephala, } \\
\text { (Lam.) de Wit }\end{array}$ & Ipil-ipil & Not threatened & $\begin{array}{l}\text { Seeds and leaves as food, seed as deworming } \\
\text { agent, leaves as feed supplement, carvings, } \\
\text { firewood, used in paper and rayon industries }\end{array}$ \\
\hline Coconut & Arecaceae & C. nucifera, $\mathrm{L}$. & Lubi & Not assessed & $\begin{array}{l}\text { Food, lumber, building materials, décor, } \\
\text { firewood }\end{array}$ \\
\hline Bagras & Myrtaceae & $\begin{array}{l}\text { E. deglupta, } \\
\text { Blume) }\end{array}$ & Eucalyptus/Dinglas & Not assessed & $\begin{array}{l}\text { Ornamental, medicines, manufacture paper } \\
\text { and furniture, leaves extract for oil } \\
\text { aromatherapy }\end{array}$ \\
\hline Guava & Myrtaceae & P. guajava, L. & Bayabas & Not a & Food, medicines \\
\hline Datiles & Muntingiaceae & M. calabura, L. & Mansanitas & Not assessed & Food, medicines \\
\hline Banana & Musaceae & $\begin{array}{l}\text { M. acuminata, } \\
\text { Colla }\end{array}$ & Saging & Not assessed & Food and vitamin source \\
\hline $\begin{array}{l}\text { Makahiya } \\
\text { Rosaria grass }\end{array}$ & Fabaceae & M. pudica, L. & $\begin{array}{l}\text { Hibi-hibi } \\
\text { Rosaria }\end{array}$ & Not threatened & Medicines \\
\hline Cogon & Poaceae & $\begin{array}{l}\text { I. cylindrica, (L.) } \\
\text { Raeusch. }\end{array}$ & Cogon & Not assessed & Handicrafts, medicines \\
\hline
\end{tabular}




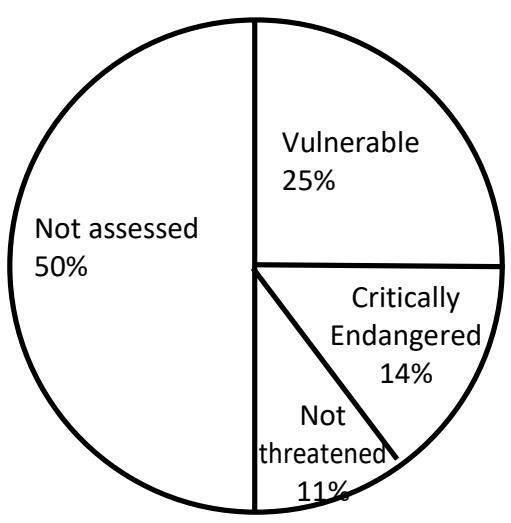

Figure 3. Percentage distribution of the conservation status of angiosperm species

As presented in Table 2, plants are arranged based on their International Union for Conservation of Nature (IUCN) Red List as considered to be critically endangered and vulnerable status with possible global extinction (IUCN-Red Data Book 2020). It can be noted in Table 2 that approximately 75 percent of plant composition is tree species. The last column on uses projects the critically endangered and vulnerable trees utilized in many construction materials, boat making, furniture and carvings, plywood, and even firewood. They display a huge variety of life forms, including trees, herbs, shrubs, grasses, submerged aquatics, bulbs, and epiphytes. Moreover, diverse angiosperms species are the main sources of food and the medicines that all people globally use for curing different diseases. They are primary sources of consumer goods, including building materials, textile fibers, spices and herbs, and pharmaceuticals. Some trees and shrubs species have high carbon sequestration, which can function as reducers of carbon dioxide load in the atmosphere, particularly in areas with high air pollution levels (Christenhusz and Byng 2016). The various uses of these tree species are an important indicator of high demand in the market, making their presence susceptible to loggers who are unconcerned about the plant status (Hawkins et al. 2011).

In addition, it is relevant to note the conservation status is based on the International Union of Conservation Nature (IUCN) of the various angiosperm species as shown in Table 2, where tree species are in the line of critically endangered species and vulnerable status. There were 3 critically endangered plant species as found in the IUCN, namely: Yakal (S. astylosa, Fox.), Narra ( $P$. indicus, Willd.), and Philippine Teak (T. philippinensis, Benth. \& Hook.f.); 3 vulnerable, Large-leaf Mahogany ( $S$. macrophylla, King), Molave (V. parviflora, Juss.), and Antipolo (A. Blanco, (Elmer) Merr.), 1 for not threatened, the Ipil-ipil (L. leucocephala, (Lam.) de Wit.) and 1 for least concern, the Makahiya (M. pudica, L.). However, 6 plant species are not in the Red List of International Union Conservation of Nature (IUCN) including a coconut tree (C. nucifera, L.), Datiles (M. calabura, L.), Banana ( $M$. acuminata, Colla), Barras (E. deglupta, Blume), Guava ( $P$. guajava, L.), and lastly, Cogon (I. cylindrica, (L.)
Rausch.). Figure 3 shows the IUCN status of the plant species in the site, and $50 \%$ of them are not yet evaluated since some of them are not identified presently by local foresters in the province which are observable in unprotected areas since they are not well assessed (León-Ortega 2017).

In summary, $75 \%$ of compositions are tree species, dominating the site's vast area, and $50 \%$ are left unassessed. The City Tourism of Butuan City and DENRlocal satellites have no record of the number of plant species present in the area, just the plant list but have no quantity available.

\section{Bood promontory and eco-park community participation}

The country is one of the pioneering implementers of Community Based-Forest Management Program in Asia (Peras et al. 2015). It recognized the urgent need for effective action to minimize the negative upstreamdownstream and on-site-off-site impacts of forest management externalities (Wallace 2014). Therefore, it adopted the Community-Based Forest Management (CBFM) Program which promotes the overall strategy of the government towards the management and protection of the forest and forestlands through Executive Order (EO) No. 263 s. 1995 identifies local forest communities and people's organizations as the immediate stakeholders of the forestland resources in the protection and management of the forest ecosystems (Aquino and Daquio 2014). The government warranted that through these actions, the forestlands will be conserved, and the decline of forest cover will be minimized, for these will cause a significant loss of biodiversity and wildlife habitat (Salzer 2012).

In the instance of Bood Promontory and Eco-Park, it is not yet a protected area, only ranks 6 on the priority list of the City Tourism's Office, and partially managed by two communities from conflicting barangays' Pinamanculan and Libertad. The following scenarios will be of help to understand the case.

On the side of Barangay Libertad, their local tourism benefits from all tax revenues and incomes while Barangay Pinamanculan is just a plain farmland user for the majority of the farmers, 328 out of 528 were from this barangay (Barangay Profile 2018). Both barangays have limited participation in the management of the eco-park for the full in-charge is the City Tourism. They are restricted only on the partial protection and monitoring of the natural resources, specifically on the hardwoods and some cleanup activities. They have no written documents, just an internal agreement of the present Barangay Council regarding the use of the 72-hectares land and some resources allowed by the City Tourism Office as the core managing government agency but no stipulated boundaries of quantities and qualities regarding the sustainability of the natural resources. However, the Barangay Council in dispute have made some initiatives as they agreed on the policy on "No cutting of trees" as the main thrust. They spent some efforts to help the Department of Environment and Natural Resources (DENR)-local satellite in protecting the various trees from illegal loggers, especially the 
hardwoods. They can cut matured Falcata Trees (Wood used for manufacturing paper) but with a proper permit from DENR. They also assigned farmers residing nearby the eco-park to be the eco-watchers. They have a quarterly schedule for solid waste monitoring and cleaning in Bood Eco-Park down to Masao River (DENR \& City Tourism 2018) as well as tree monitoring and replanting for those seedlings which do not survive during the reforestation period. Some parts of the 30 hectares were planted with Falcata trees, fruit trees, bamboos, coconut trees, and rice for lower plains that are not swampy, while the $42-$ hectare lands are the center of the eco-park, the "bood" or hill. There were no recognized peoples' organization involved in managing the land area, but local farmers are involved as eco-watchers and land users, and there were local organizations involved in some of the activities such as Couples-Singles for Christ (CFC-SFC), Boy Scout of the Philippines-Butuan Chapter, and Rotary Club of Butuan, who actively participated in clean-up activities down to Masao River and conducts tree-planting drive activities.

In addition, based on the information and background of the status of the community management portrayed by two barangays, we can say that they are on delegating type or in participatory conservation. According to the idea of the spectrum of generic types of community-based forestry, delegate type with a generic description of participatory conservation has key characteristics that some community responsibility to protect forests (Šimunović et al. 2018) but little authority to make decisions and very few or no rights for local communities to access and use forest products (Gilmour 2016). The indicative rights are the following: (a) they have rights to access forest but no rights to make forest management decisions, (b) no rights to determine who will have access to forest and no rights to sell or lease the land or use them as collateral, (c) no defined term for the duration of rights, and (d) no rights to obtain compensation.

\section{Best practices}

The Bood Promontory and Eco-Park is not a protected area and only a partial community-based-managed ecological park. However, the efforts extended by these two barangays, Pinamanculan and Libertad, help in sustaining the natural resources are impactful, even though they were at the point of disagreement regarding the claim of the land. The initiatives they have done to watch over the trees, particularly guarding on the hardwoods are considered critically endangered and vulnerable (Lillo et al. 2019). The quarterly monitoring and cleaning activity they extended on the solid waste problem in Masao River deserves an appreciation, although the action is not enough, at least they shared collaborative efforts together with the local organizations. No one is paid in all their activities on these efforts; the entirety is voluntary. They showed proper coordination with the LGU, heeding on the internal agreements they set upon, are important gestures sustaining such a course. Furthermore, the City Tourism has allotted two janitors to maintain the cleanliness in the vicinity of the park and a manager under a contract of service (COS) status for the eco-park management. The park is already on the list of travelers visiting Butuan City. The number of foreign and local visitors has increased dramatically from 1,709 to 11,629 in 2016 and 2019, respectively, based on the report acquired from the report of the City Tourism Office.

\section{Challenges and perspectives}

The Bood Promontory and Eco-Park remain a nonprotected area. Only a partial community involvement depending on who sits in the office of the barangay council for the obligation based on the internal agreement relies primarily on the commitment of the incoming sets of barangay officials, headed by a barangay chairman. The barangay organization changes every after 3 years, the conservation efforts and participation also change as this depends on the horizon to be taken by another set of officials. If this is not part of the line, then efforts surely will not be spent on these and will bring an unacceptable impact to the natural resources (Meijers et al. 2016). The various angiosperms accounted in the place are just initial data that brings a picture for the active participation of the community, especially the farmers who did play a significant role. The continuous existence of hardwood is critically endangered, and vulnerable status indicates that small efforts spent on these are effective (Sobral et al. 2017). Does the big question rely on sustaining the efforts and involvement for protection when the administration constantly changes? The farmers who served as forest protectors may not be committed when left untapped by the new sets of officials in the barangay council, bringing the natural resources into peril. They might resort to conscious and subconscious sabotage of resources (Maetzkea and Cullotta 2016). The City Tourism and DENR must hasten the application for protection management to completely set a management plan that can permanently and fully involve the community as partners in sustaining the management, thereby saving the plant species and biodiversity that still needs further assessment (Heywood 2019).

Managing the Bood Promontory and Eco-park as a nonprotected area and partial involvement of the community remains an excessive challenge. However, some possible concepts can be used to brighten the horizon, solving the dispute between the two barangays: Pinamanculan and Libertad, and achieved a full devolution type of community-based protection management program. Priority wise, the two barangay councils must convene and materialize an agreement such as the formulation of resolution and ordinances, that both will benefit and sustainable to every immediate land user-the resident farmers.

Dealing with conflicts is an excessive challenge to management (Rasul 2016); hence, the following suggestions will be useful in addressing the disputed barangays.

Firstly, there should be participatory mapping exercises among community members to reach an agreement on boundaries and help bring the land disputes to light. This mapping system will become the emerging tool to allow remote and local communities to represent themselves as 
the steward of protecting the areas with the help of their local knowledge to gain the attention of the governmental authorities and to become decision-makers that help protect the disputed areas of concern. For this reason, one proposed program is to establish a computer-based Geographic Information System (GIS) or satellite imagery to monitor the area even without the presence of the authorities as a way of monitoring and protecting the natural resources in the area from unscrupulous people wanted to destroy the eco-park for their personal interest and consumptions. The put up of GIS will become important to gather information on traditional knowledge and practices, collect data for land and forest assessments and present alternative scenarios to empower as well as educating stakeholders (Boudreaux et al. 2017). The data of the angiosperm species are valuable for this mapping, to serve as an overview of the community that plant varieties are found in various locations of the 72-hectare area coverage. They can agree for a resolution to use the appropriated land based on the demarcation of the line where resources are at par on both parties, which is to be reflected on a forest density map-a basic tool for forest management and plan (Kraxner et al. 2017). To this, the City Tourism and DENR must work together to reach a complete inventory of all flora and fauna found in the place to have a full view of the species that require attention for protection and sustainable conservation.

Secondly, they can agree to share the yearly profits from tax revenues and other sources of income with transparency and legal auditing, since now, it is only Barangay Libertad who is enjoying the direct monetary aspect and one has to take note, that financial facet is one of the main causes of conflict in management (Ongori 2009).

Finally, if the protected areas application warrants, the council can apply and register for a People's Organization (PO) that can open the opportunity for a community basedprotection management plan that has full participation among subordinates. Taking into account the ecological, social, and policy imperatives (Aquino and Daquio 2014) proposed strategic features for having local communitybased management program, namely: (a) develop fairness to all and observed in granting forest communities as well as inclusive rights to use forest resources; (b) improve the mechanism for legitimizing natural resource access and local rights on the issuance of authentic tenurial arrangement; (c) DENR and LGU partnership, which they can provide technical assistance to the members to help them attain sustainable forest management, and (d) Investment Capital and Market Linkage, the organization helps the members access investment capital, identify markets and build marketing capabilities. The program integrates and unifies people-oriented local forestry activities of the Integrated Social Forestry Program, Community Forestry Program, Coastal Environment Program (Domingo and Manejar 2018) which bring people together that work on a common good, resolving various conflicts and maintains open communication to achieve a functional participating community based on workable management plan.
In addition, they can also apply the DENR Administrative Order No.123 concerning the Community Forestry Management Agreement (CFMA) to organize upland communities for a period of 25 years, renewable for another 25 years and forest utilization privileges are given to the communities which are expected to prepare a development plan and adhere to the principles of sustainedyield management, and strengthen it through Executive Order (EO) No. 263, taking the Adoption of CommunityBased Forest Management (CBFM) as the national strategy for the sustainable development of forestlands and foster social justice (Niraula et al. 2013).

The researchers believe that these valuable inputs will bring light to these endeavors, nonetheless, these will only be left in limbo if the forefront if the agency will not begin a single step for initiating the Bood Promontory and EcoPark conservation and protection.

\section{Strengthening the management of protected areas}

The Philippine government officials welcomed the signing into law the Republic Act 11038, or the Expanded National Integrated Protected Areas System (E-Nipas 2018) Act for biodiversity conservation which promotes and strengthens the management of protected areas in the country, and to protect and conserve the country's rich biodiversity against various threats. As suggests, E-Nipas expands the areas covered and the number of protected areas and eco-parks declared as mandated by local and national regulations or rulings, on commanding a stricter consequence and higher penalties against environment kaingiros (slash-and-burn cultivators) and forest loggers.

So, amidst these provisions, the E-Nipas Act suggests the following: (i) Stronger protection. As of the present, there are an estimated 240 protected areas under E-Nipas, but only around 13 protected areas are aided by-laws, while presidential proclamations protect the orders of the remaining area. These areas are said to be the initial components and possibly be relinquished by the Environment and Natural Resources (DENR) upon the recommendation of the Protected Area Management Board (LAMB) as the supreme policy-making organization of a protected area in the country, (ii) Expanded coverage. For policy, planning, and international must fulfills that ENipas law adds more protected areas that are backed with legislation covering the land area, both in the terrestrial and marine territory, (iii) stronger adaptive capacity. With this law, it must expect that it has a more proactive local government unit (NGOs) to form the Protected Area Management Board (PAMB) and formulate their respective protected area management plan. In this regard, the woodlands are the state's major carbon sink. Thus, it aims to diminish its carbon emissions by a whopping 70 percent, started from 2020 to 2030 as part of its commitment underneath 2015 Paris Agreement, (iv) Salient provisions. So, among the salient provisions of the law are scientific and technical support for biodiversity conservation; delimitation and delineation of borders; delegation of support system implementation, constant update, and reporting on the status of the area of concern and protection. Thus, the news enlightens the country's 
citizens. As mentioned, the Aichi Biodiversity Target 11 states that "by 2020 , at least 17 percent specifically on terrestrial are conserved through effectively and equitably managed, ecologically representative, and well-connected systems of protected areas and other effective area-based conservation measures.

It is hoped that this law, if accurately enforced, will support the government to maximize the welfares of its rich biotic diversity, and gauge up these efforts and benefits at the regional and even up to the national level since the benefits of protected areas are elaborated, thus, protected areas are an important scheme for the emerging ground of nature-based key solutions to several challenges and issues.

In conclusion, in general, the inventory of the angiosperm species in bood promontory and eco-park provides initial data as a benchmark for eco-forest management assessment, updating their record, and giving them a picture that there is really a need to have a repository of the plant species for extinction without the chance of being assessed as an area of concern. The data represents a portion of the whole picture of the plant species of the place, but it is a prevailing starter for all these endeavors, realizing that the site is a rich haven of plant biodiversity as well as recognizing numbers of dominant trees are on the verge of critically endangered and vulnerable status. The management system must give divergent attention and continually tapped the community, specifically the farmers, and concern local agencies for protection. On the other hand, the existing conflicts between the two barangays did not hinder them from protecting and monitoring the plant species and even protecting the Masao River, though partial but at least functional. They need to come up with a doable management action plan for easy, smooth sailing, and flow of concrete eco-park protection and clean-up drive activities. The DENR and City Tourism must accelerate the warrant for protecting the area to build a stable Community-Based Protection Management Program and create a constructive resolution to form a functional people's organization that will fully participate in the sustainability of the eco-park to become a communitymanaged area by local communities.

\section{ACKNOWLEDGEMENTS}

The authors would like to acknowledge the efforts of the team and the active support of Barangay Bood Promontory and Eco-Park Management through Mr. Conrado B. Marquez (Head, FTRRC Satellite Office, Bood, Pinamanculan, Butuan City), Mr. Jomar C. Palac (Science Research Technician-I), Genalyn Gumata (Research Aide), Metes B. Agunat (Forest Technician-I) and Jessie Preglo (Tree Climber/Arborist), the Barangay Council of Pinamanculan and Libertad, and Butuan Library. The authors declared no conflict of interest involved in this study.

\section{REFERENCES}

Ahmad H, Sakshi S, Anurag M, Rajiv G. 2012. Mimosa pudica L. (Laajvanti): An overview. Pharmacogn Rev 6 (12): 115-124. DOI: 10.4103/0973-7847.9 9945.

Amano N, Bankoff G, Findley D, Barretto-Tesoro G, Roberts P. 2020. Archaeological and historical insights into the ecological impacts of pre-colonial and colonial introductions into the Philippine Archipelago. The Holocene 31 (2): 313-330. DOI: 10.1177/0959683620941152.

Aquino A, Daquio C. 2014. CBFM: A National Strategy for Sustainable Forest Management. Agricultural Policy Articles. FFTC J Agri Plc., Taiwan.

Araneta C. 2021. First holy mass controversy in the Philippines. The $\begin{array}{lll}\text { Manila Times. https://www.manilatimes.net/202 } & 1 / 0\end{array}$ 3/07/opinion/analysis/first-holy-mass-controversy/848118/

Barangay Profile. 2018. Butuan City demographic profile of barangay. PhilAtlas, $2018 . \quad$ https://www.philatlas.com/mind anao/caraga/butuan.html

Boudreaux K, Vhugen D, Walter N. 2017. Community and conflicts: how local land disputes affect private sector investments and development projects. UK Department of International Development, London, UK. DOI: $10.1016 /$ j.marpol.2017.03.003.

Butuan City Tourism Council. 2021. City map of Batuan. Tourism Council, Butuan City, Philippines.

Capistrano-Baker F. 2016. This catalogue accompanies the exhibition Philippine Gold: Treasures of forgotten kingdoms. Asia Soc 2015, HC, 100. DOI: 10.1215/00666637-4229719.

Chechina M, Hamann A. 2016. Choosing species for reforestation in diverse forest communities: social preference versus ecological suitability. Ecosphere 6 (11): 1-13. DOI: 10.1890/ES1 5-00131.1.

Christenhusz M, Byng J. 2016. The number of known plant species in the world and its annual increase. Phytotaxa 261 (3): 201-217. DOI: $10.1111 /$ boj.12385.

CIFOR. 2019. Science and development excellence that harnesses the benefits of trees for people and the environment. Center for International Forestry Research, Bogor.

D'Arcy P. 2018. The Philippines as a Pacific Nation: A brief history of interaction between Filipinos and Pacific Islanders. J Pac Hist 1-23. DOI: 10.1080/00223344.2018.1461007.

DENR-APWB, CI, UPCIDS. 2002. Establishment, management and development of the national integrated protected areas system. Forest Management Bureau, Philippines.

Domingo S, Manejar A. 2018. Forest protection in the Philippines. EconStor. https://www.econstor.eu/handle/1 0419/211073

E-NIPAS Law. 2018. Republic Act 11038 or the law expanding the national integrated protected areas system. The Phil. Star. https://www.philstar.com/headlines/2018/07/09/1831853/e-nipas-lawprotect-94-more-critical-habitats

Estrella V. 2016. The gold working sub-assemblage from Butuan, northeast Mindanao, Philippines: The archaeological record. Proceedings of the Society of Philippine Archaeologists, Manila.

Gamas J. 2020. Butuan in the pre-colonial Southeast Asian international system. Studies in the Philippines: Mapping New Frontiers. Routledge, New York.

García-Quintanaa Y, Crespoa, Y, Navarretea B, Morillob M, Medinaa C, Sarmiento A. 2020. Ecological quality of a forest in a state of succession based on structural parameters: A case study in an evergreen Amazonian-Andean forest, Ecuador. Heliyon J 6 (7): e04592. DOI: 10.1016/j.heliyon.2020.e04592.

Gilmour D. 2016. Forty years of community-based forestry (CBF): A review of its extent and effectiveness. FAO, Rome.

Hawkins B, Rodriguez M, Weller S. 2011. Global angiosperm family richness revisited: linking ecology and evolution to climate. $\mathrm{J}$ Biogeogr 38: 1253-1266. DOI: 10.1111/j.1365-2699.2011.02490.x.

Heywood V. 2019. Conserving plants within and beyond protected areasstill problematic and future uncertain. Plant Divers 41 (2): 36-49. DOI: $10.1016 /$ j.pld.2018.10.001.

IUCN Red List of Threatened Species. 2020. Authoritative Guide to the Status of Biological Diversity. IUCN, London. https://www.iucn.org/

Jackson E. 2020. Ferdinand Magellan's voyage and its legacy in the Philippines. Proceedings of the national conference on undergraduate research (NCUR) 2020. Montana State University, Bozeman, MT.

Kraxner F, Schepaschenko D, Fuss S, Lunnan A. 2017. Mapping certified forests for sustainable management-A global tool for information 
improvement through participatory and collaborative mapping. For Pol Econ 83: 10-18 DOI: 10.1016/j.forpol.2017.04.014.

Larekeng S, Restu1 M, Arsyad M. 2019. Observation of morphological and physiological characteristics on abangares mahogany (Swietenia macrophylla King.) in South Sulawesi. IOP Conf Ser Earth Environ Sci 270: 012022. DOI: 10.1088/1755-1315/270/1/012022.

León-Ortega M, Martínez J, Pérez E, Lacalle J, Calvo J. 2017. The contribution of non-protected areas to the conservation of Eurasian eagle-owls in Mediterranean ecosystems. Ecosphere 8 (9): E01952. DOI: $10.1002 /$ ecs2.1952.

Lillo E, Archiebald B. Malaki1 A, Alcazar T, Nuevo R, Rosales R. 2019. Native trees on Mount Lantoy key biodiversity areas (KBA), Argao, Cebu, Philippines. Phil J Sci 148 (2): 359-371.

Maetzkea F, Cullotta S. 2016. Environmental and forest planning in Italy: conflicts and opportunities. Agric Agric Sci Procedia 8: 332-338. DOI: $10.1016 /$ j.aaspro.2016.02.028.

Maiti R, Rodriguez H, Kumari C. 2016. Wood density of ten native trees and shrubs and its possible relation with a few wood chemical compositions. Am Plant Sci 7 (8): 1192-1197. DOI: 10.4236/ajps.2016.78114.

Meijers F, Lengelle R, Kopnina H. 2016. Environmental identity and natural resources: A dialogical learning process. MDPI J 5 (1), 11. DOI: 10.3390/resources5010011.

Niraula R, Gilani H, Pokharel B, Qamer F. 2013. Measuring impacts of community forestry program through repeat photography and satellite remote sensing in the Dolakha district of Nepal. J Environ Manag 126, 20-29. DOI: 10.1016/j.jenvman.2013.04.006.

Ongori H. 2009. Organisational conflict and its effects on organisational performance. Res J Business Manag 3: 16-24.

Peras R, Pulhin J, Inoue M. 2015. Local stakeholders' assessment of community-based forest management and the implications for REDD
Plus implementation in the Philippines. Asian Intl J Life Sci 24 (1): 349-381. DOI: 2015/3326/302.

PFS-DENR. 2019. Forest resources and activities in the Philippines. Forest Management Bureau, Philippines.

Rasul G. 2016. Managing the food, water, and energy nexus for achieving the sustainable development goals in South Asia. Environ Dev 18: 1425. DOI: 10.1016/j.envdev.2015.12.001.

Salzer W. 2012. Factsheet: Environment and rural development (EnRD) program Philippines. Component 4: Community Based-Forest Management, FFTC J Agri Plc., Taiwan. https://ap.fftc.org.tw/article/714.

Šimunović N, Hesser F, Stern T. 2018. Frame analysis of ENGO conceptualization of sustainable forest management: Environmental justice and neoliberalism at the core of sustainability. Sustainability 10 (9): 3165. DOI: 10.3390/su10093165.

Sobrala A, de los Ángeles M, Romeu R, Alvesd N, Albuquerquea U. 2017. Conservation efforts based on local ecological knowledge: The role of social variables in identifying environmental indicators. Ecol Indic 81: 171-181. DOI: 10.1016/j.ecolind.2017.05.065.

Volis S. 2016. How to conserve threatened Chinese plant species with extremely small populations? Key laboratory for plant diversity and biogeography of East Asia. Plant Divers 38 (1): 45-52. DOI: 10.1016/j.pld.2016.05.003.

Wallace M. 2014. Philippine forests: Private privilege or public preserve? International association for the study of common property. World Agroforestry Center, Kenya. http://www.worldagroforestry.org/

Wu S, Li S. 2018. Natural resource abundance, natural resource-oriented industry dependence, and economic growth: Evidence from the provincial level in China. Res Conserv Recycling 139: 163-171. DOI: 10.1016/j.resconrec.2018.08.012.

Yu S. 2020. Paraisong Nawala (Lost Paradise): Exploring Sustainable Ecotourism in the Philippines. [Thesis]. Claremont Colleges, California. 